\title{
Pengaruh Kombinasi Emulgator CMC dan Tween 80 Terhadap Stabilitas Fisik Emulsi Minyak Ikan
}

\section{Combination Effect of CMC Emulsifier and Tween 80 Againts Stability of Fish Oil Emulsion}

Retnowati Adiningsih

Farmasi Universitas Setia Budi

\begin{abstract}
Intisari
Emulsi minyak ikan dalam formula standar menggunakan emulgator gom arab yang mempunyai sifat emulgator sejati. Gom ini mempunyai kerugian yaitu penyimpanan yang lama dapat menyebabkan hilangnya daya mengemulsinya, sehingga berdasarkan hal tersebut tidak menutup kemungkinan untuk menggunakan emulgator lain yaitu CMC dan Tween 80 . Penelitian ini bertujuan untuk mengetahui pengaruh kombinasi emulgator CMC dan Tween 80 terhadap stabilitas fisik minyak ikan dan konsentrasi emulgator CMC dan Tween 80 yang optimal untuk membuat emulsi minyak ikan yang stabil, ditunjukkan dengan tidak adanya kerusakan yang berarti dari emulsi selama penelitian.

Penelitian ini menggunakan 4 formula dengan kandungan kombinasi emulgator yang bervariasi yaitu CMC 0,25\% ; CMC 0,25\% : Tween $8010 \%$; CMC 0,25\% : Tween 80 20\% ; Tween 80 20\%. Pengamatan stabilitas emulsi meliputi tipe emulsi, persen pemisahan pada suhu kamar, pada suhu $40^{\circ}$ $50^{\circ} \mathrm{C}$, pada sentrifugasi $3000 \mathrm{rpm}$, viskositas dan penentuan ukuran patikel.

Hasil yang didapat pada penelitian ini menunjukkan adanya variasi stabilitas emulsi minyak ikan dari tiap-tiap kombinasi emulgator. Hasil statistik menunjukkan bahwa emulgator CMC 0,25\% berpengaruh nyata terhadap persen pemisahan pada suhu kamar, suhu $40^{\circ}-50^{\circ} \mathrm{C}$, sentrifugasi 3000 rpm, viskositas dan ukuran partakel emulsi minyak ikan. Emulsi dengan kombinasi emulgator CMC 0,25\% : Tween 80 20\% merupakan emulsi yang paling stabil karena pada pemeriksaan persen pemisahan, viskositas dan ukuran partikel mempunyai stabilitas fisik yang lebih baik dibanding formula lain.
\end{abstract}

Kata kunci: CMC, Tween 80, Stabilitas fisik, Emulsi minyak ikan.

\begin{abstract}
Cod-liver oil emulsion in standard formula using gum arabic as emulsifying agent is considered to be "true" emulsifier. The disadvantage of gum arabic is it cannot be stored in along time because the emulsifier effect will vanish, so it has to be combined with other emulsifying agent such as CMC and Tween 80. The aim of the experiment was to study the influence of CMC and Tween 80 emulsifiers combination on physical stability of cod liver oil emulsion and the optimal concentration of CMC and Tween 80 emulsifiers to prepare a stable cod liver oil emulsion, indicated by there was no significant damage of the emulsion during the experiment.

The experiment used 4 formulas which contain emulsifiers combinations: 0,25\% CMC; 0,25\% CMC : $10 \%$ Tween $80 ; 0,25 \%$ CMC : $20 \%$ Tween 80; $20 \%$ Tween 80 . The observation of emultion stability includes emulsion type, separation percentage at room temperature, at $40^{\circ}-50^{\circ} \mathrm{C}$
\end{abstract}


temperature, at $3000 \mathrm{rpm}$ centrifugally, viscosity and particle size determination.

The result of the experiment indicated there was various stability of cod liver oil emulsion in each emulsifier combination. The statistic result indicated that CMC $0,25 \%$ had significant influence on separation percentage at room temperature, at $40^{\circ}-50^{\circ} \mathrm{C}, 3000 \mathrm{rpm}$ centrifugally, viscosity and particle size of cod liver oil. Emulsion with emulsifiers combination of $0,25 \%$ CMC : 20\% Tween 80 was the most stable emulsion because at the separation percentage examination, the viscosity and particle size had the best physical stability compared with other formula.

Keywords: CMC, Tween 80,Physical stability, Cod liver oil emulsion.

\section{Pendahuluan}

Emulsi adalah sistem dispersi kasar yang secara termodinamik tidak stabil, terdiri dari minimal dua atau lebih cairan yang tidak bercampur satu sama lain, dimana cairan yang satu terdispersi di dalam cairan yang lain dan untuk memantapkannya diperlukan penambahan emulgator (Voigt, 1995).Berdasarkan penggunaan emulsi dalam bidang farmasi, emulsi dibedakan menjadi dua yaitu emulsi untuk kebutuhan dalam (emulsi minyak ikan, emulsi paraffin) dan emulsi untuk kebutuhan luar (liniment calcis) (Voigt, 1994).

Pemilihan emulgator merupakan salah satu faktor yang harus diperhatikan dalam stabilitas emulsi, dimana harus sesuai dan optimal dengan tipe sediaan emulsi, sehingga emulgator yang dipilih dapat bercampur dengan zat lainnya bersifat inert serta relatif murah (Lachman, dkk, 1986).Emulgator adalah senyawa-senyawa yang menurunkan tegangan permukaan, disebut juga dengan tensid.Tensid adalah senyawa yang memiliki gugus lipofil dan hidrofil dalam molekulnya (Voigt, 1994).

Emulgator menurut asalnya ada dua macam yaitu emulgator dari alam dan emulgator dari bahan sintetik. Beberapa contoh emulgator dari alam yaitu gom arab atau akasia, agar dan tragakan. Beberapa contoh emulgator bahan sintetik yaitu karboksi metil selulosa Natrium atau CMC, metil selulosa atau MC, hidroksi etil selulosa atau HEC, povidone atau PVP dan stearil alkohol (Nanizar, 1998).
Emulgator dapat dikelompokkan menjadi emulgator ionik, termasuk ke dalamnya anion aktif (anionik) contoh: natrium stearat, natrium palmitat, emulgator kation aktif (kationik) contoh: benzalkonium bromida, emulgator bukan ionik contoh: Tween, span, setil alkohol dan emulgator amfoter, contoh: protein, lesithin.

Tween 80 adalah hasil kondensasi oleat dari sorbitol dan anhidridanya dengan etilenoksida.Tween digunakan sebagai emulgator $5 \%$ - $10 \%$ dari fase minyak.

CMC merupakan garam sodium dari polikarboksi metil selulosa yang larut dalam air serta stabil pada $\mathrm{pH}$ antara 5-10, jadi larutan ini memiliki $\mathrm{pH}$ netral. CMC dalam konsentrasi sedang mempunyai efek yang kecil terhadap stabilitas emulsi, sebaliknya dalam konsentrasi besar akan menurunkan stabilitas emulsi (Martin dkk, 1959).

Minyak ikan adalah minyak lemak hasil destearisasi sebagian dari minyak lemak hati segarGadus marbua L dan spesies lain dari familia Gadiae. Minyak ikan berupa cairan minyak encer, berbau khas, tidak tengik, rasa dan bau seperti ikan (Anonim, 1995).

Emulsi minyak ikan dalam formula standar yaitu Formularium Nasional menggunakan emulgator gom arab yang mempunyai sifat emulgator sejati. Gom ini mempunyai kerugian yaitu harus digunakan dalam konsentrasi yang tinggi (> 5\%). Penyimpanan kering yang lebih lama dapat menyebabkan hilangnya daya mengelmusinya (Voigt, 1994). 
Berdasarkan hal-hal tersebut di atas tidak tertutup kemungkinan digunakan kombinasi emulgator CMC dan Tween 80 pada emulsi minyak ikan, karena itu diadakan penelitian tentang pengaruh besarnya konsentrasi kombinasi emulgator CMC dan Tween 80 terhadap stabilitas emulsi minyak ikan. Penelitian ini bertujuan untuk mengetahui pengaruh kombinasi emulgator CMC dan Tween 80 terhadap stabilitas emulsi minyak ikan dan konsentrasi kombinasi emulgator CMC dan Tween80 yang optimal untuk membuat emulsi minyak ikan agar mempunyai stabilitas yang baik. Hasil penelitian imi di harapkan dapat berguna dalam industri farmasi dan bermanfaat untuk kepentingan ilmu pengetahuan

\section{Metode}

A. Bahan dan Alat

Bahan yang digunakan adalah minyak ikan (kualitas farmasi), CMC (kualitas farmasi), Tween 80 (kualitas farmasi), aquadestilata, gliserin dan oleum citri.

Alat yang digunakan adalah blender elektrik, viskometer Rion VT-04, sentrifuge, neraca analitik Mettle Toledo $\mathrm{Pb}$ 303, termasuk alat-alat gelas yang digunakan.

B. Jalannya Penelitian

1. Pemeriksaan kualitatif bahan baku

2. Formula

Tabel I. Formula Persentasi kombinasi CMC dan Tween 80 sebagai emulgator tiap

\begin{tabular}{c|c|c}
\multicolumn{3}{c}{ formula } \\
\hline Formula & CMC & Tween 80 \\
\hline A & $0,25 \%$ & - \\
B & $0,25 \%$ & $10 \%$ \\
C & $0,25 \%$ & $20 \%$ \\
D & - & $20 \%$ \\
\hline
\end{tabular}

Tabel II. Formula emulsi minyak ikan dengan kombinasi emulgator CMC dan Tween 80

\begin{tabular}{l|c|c|c|c}
\hline \multirow{2}{*}{ Formula } & \multicolumn{4}{|c}{ Komposisi } \\
\cline { 2 - 5 } & $\mathrm{A}$ & $\mathrm{B}$ & $\mathrm{C}$ & $\mathrm{D}$ \\
\hline Minyak ikan & $100 \mathrm{~g}$ & $100 \mathrm{~g}$ & $100 \mathrm{~g}$ & $100 \mathrm{~g}$ \\
CMC & $0,538 \mathrm{~g}$ & $0,538 \mathrm{~g}$ & $0,538 \mathrm{~g}$ & - \\
Tween 80 & - & $10 \mathrm{~g}$ & $20 \mathrm{~g}$ & $20 \mathrm{~g}$ \\
Glyserin & $10 \mathrm{~g}$ & $10 \mathrm{~g}$ & $10 \mathrm{~g}$ & $10 \mathrm{~g}$ \\
Nipagin & $0,215 \mathrm{~g}$ & $0,215 \mathrm{~g}$ & $0,215 \mathrm{~g}$ & $0,215 \mathrm{~g}$ \\
Oleum Citri & $\mathrm{gtt} \mathrm{VI}$ & $\mathrm{gtt} \mathrm{VI}$ & $\mathrm{gtt} \mathrm{VI}$ & $\mathrm{gtt} \mathrm{VI}$ \\
Aquadestillata & $\mathrm{ad} 215 \mathrm{~g}$ & $\mathrm{ad} 215 \mathrm{~g}$ & $\mathrm{ad} 215 \mathrm{~g}$ & $\mathrm{ad} 215 \mathrm{~g}$ \\
\hline
\end{tabular}

3. Pembuatan formula

CMC ditimbang sejumlah yang diperlukan,kembangkan dalam air panas kira-kira $1 / 2$ bagian air dalam formula dan dibiarkan sampai mengembang, kemudian diaduk sampai homogen.Mucilago ini ditambah Tween 80 aduk sampai homogen, tambahkan minyak sedikit demi sedikit diaduk dengan menggunakan blender mekanik.Bila emulsi terlalu kental, ditambah air sedikit demi sedikit agar mudah diaduk kemudian ditambah sisa minyak.Bila semua minyak sudah masuk ditambah gliserin, nipagin yang telah dilarutkan dengan air panas, oleum citri dan sisa air sambil diaduk sampai volume $215 \mathrm{~g}$, hal ini dilakukan untuk semua formula.

4. Penentuan tipe emulsi
a. Metode pengukuran daya hantar
b. Metode pemberian warna
c. Metode pengenceran

5. Pemeriksaan stabilitas emulsi
a. Persen pemisahan karena umur dan temperature
b. Persen pemisahan karena sentrifugasi
c. Viskositas 
d. Ukuran partikel

1) Penalaran skala mikroskop

2) Menentukan besarnya ukuran partikel

\section{Metode Analisis}

Stabilitas fisik emulsi yang dibuat dengan beberapa konsentrasi kombinasi emulgator CMC dan Tween 80 dapat dibandingkan melalui data yang diperoleh selama penyimpanan 4 minggu, meliputi persen pemisahan pada suhu kamar, pada suhu $40^{\circ} \mathrm{C}$ sampai $50^{\circ} \mathrm{C}$, pada sentrifugasi $3000 \mathrm{rpm}$, viskositas dan ukuran partikel. Data dievaluasi secara statistik, yaitu dengan uji Student-Newman-Keuls, untuk mengetahui formula emulsi mana yang relatif paling baik dan menguntungkan di antara formula yang dicoba dengan menentukan koefisien variasi.

\section{HASIL DAN PEMBAHASAN}

A. Hasil Penelitian

1. Pemeriksaan stabilitas emulsi

a. Identifikasi tipe emulsi

Hasil pemeriksaan tipe emulsi dengan menggunakan 3 metode memenuhi persyaratan untuk tipe emulsi $\mathrm{m} /$ a yaitu pada metode pengukuran daya hantar terjadi ayunan pada sisipan miliamperemeter, metode pewarnaan terjadi warna biru dominan jika ditambah larutan biru metilen, metode pengenceran di peroleh kembali suatu emulsi homogen jika ditambah sedikit air.

b.Persen pemisahan air dan minyak

Hasil penelitian yang dilakukan selama 4 minggu, pada emulsi minyak ikan dengan kombinasi emulgator CMC dan Tween 80 terjadi dua pemisahan yaitu pemisahan minyak pada bagian atas dan pemisahan air pada bagian bawah emulsi.

1) Persen pemisahan air pada suhu kamar

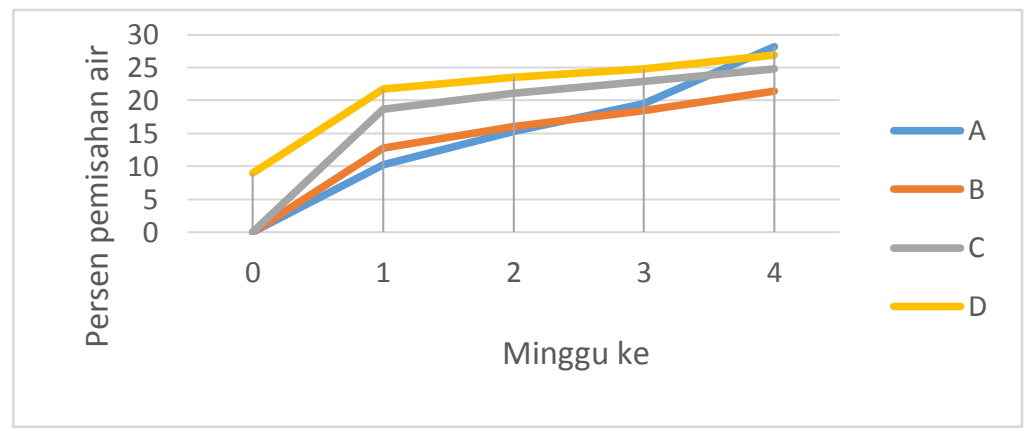

Gambar 1. Grafik hubungan persen pemisahan air pada suhu kamar dengan lama penyimpanan.

Pengamatan yang di lakukan dari semua formula menunjukkan bahwa pada minggu ke-0 belum terjadi pemisahan dan mulai menunjukkan pemisahan pada minggu ke-1 dengan rata-rata persen pemisahan formula A $10,20 \%$, formula B
$12,80 \%$, formula C $18,66 \%$, formula D $21,74 \%$ sedangkan pada minggu ke-4 ratarata persen pemisahan formula $\mathrm{A} 28,14 \%$, formula B 21,43\%, formula C $24,77 \%$, formula D 26,87\%

2) Persen pemisahan air pada suhu $40^{\circ}-50^{\circ} \mathrm{C}$ 


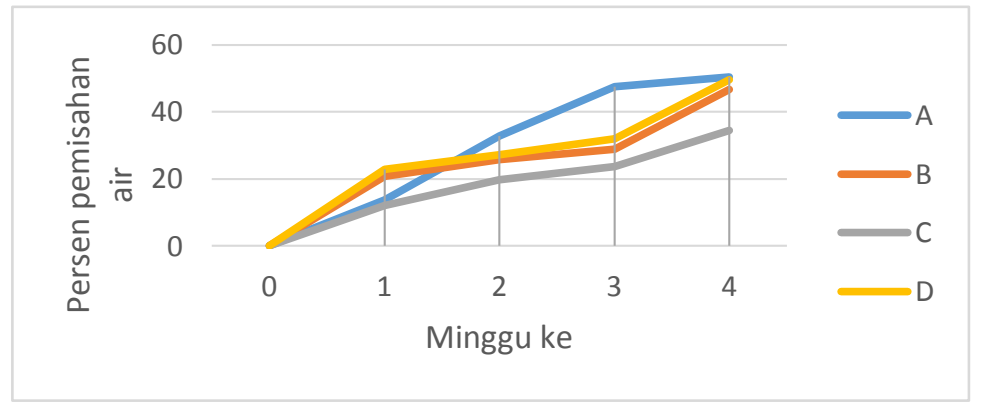

Gambar 2.Grafik hubungan persen pemisahan air pada suhu $40^{\circ}-50^{\circ} \mathrm{C}$ dengan lama penyimpanan.

Pengamatan yang di lakukan dari semua formula menunjukkan bahwa pada minggu ke-0 belum terjadi pemisahan dan mulai menunjukkan pemisahan pada minggu ke-1 dengan rata-rata persen pemisahan formula A $13,74 \%$, formula B $20,83 \%$, formula C $12,03 \%$, formula D $22,76 \%$ sedangkan pada minggu ke-4 ratarata persen pemisahan formula A 50,37\%, formula B 46,58\%, formula C 34,55\%, formula D 49,47\%.
Persen pemisahan air dari emulsi minyak ikan yang disimpan selama 4 minggu, baik pada suhu kamar maupun suhu $40-50^{\circ} \mathrm{C}$ terjadi pada minggu I. Hal ini disebabkan pada minggu I partikelpartikel terdispers bergabung membentuk partikel yang lebih besar yang menyebabkan terjadinya pemisahan fase dari emulsi.

3) Persen pemisahan minyak pada suhu kamar

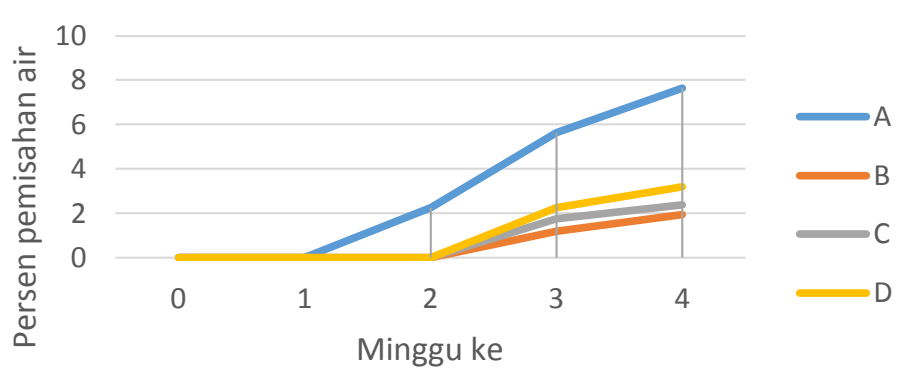

Gambar 3.Grafik hubungan persen pemisahan minyak pada suhu kamar dengan lama penyimpanan.

Pengamatan yang di lakukan dari semua formula menunjukkan bahwa pada minggu ke-0 belum terjadi pemisahan, formula A mengalami pemisahan pada minggu ke-2 dengan rata-rata persen pemisahan $2,28 \%$ sedangkan formula $\mathrm{B}$, C, D mengalami persen pemisahan pada minggu ke-3 dengan rata-rata persen pemisahan 1,19\%, 1,78\%, 2,27\%. Pada minggu ke-4 pengamatan, rata-rata persen pemisahan terbesar formula A 7,65\% dan persen pemisahan terkecil formula B $1,94 \%$.

Formula A pada minggu ke-3 telah terjadi kerusakan yang irreversibel karena dengan penggojokan ringan minyak tidak dapat di dispersikan kembali, sedang formula yang lain belum terjadi kerusakan yang irreversibel. 
4) Persen pemisahan minyak pada suhu $40^{\circ}-50^{\circ} \mathrm{C}$

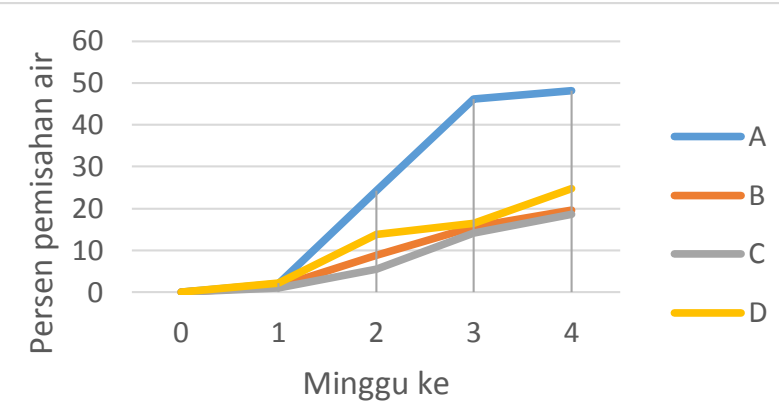

Gambar 4. Grafik hubungan persen pemisahan minyak pada suhu $40^{\circ}-50^{\circ} \mathrm{C}$ dengan lama penyimpanan.

Pengamatan yang di lakukan dari semua formula menunjukkan bahwa pada minggu ke-0 belum terjadi pemisahan dan mulai menunjukkan pemisahan pada minggu ke-1 dengan rata-rata persen pemisahan formula A $2,15 \%$, formula B $1,38 \%$, formula C $1,08 \%$, formula D $2,29 \%$ sedangkan pada minggu ke-4 ratarata persen pemisahan formula $\mathrm{A} 48,22 \%$, formula B 19,62\%, formula C 18,67\%, formula D $24,73 \%$.
Pada minggu ke-4 dari semua formula persen pemisahan minyak dan air yang paling besar pada suhu kamar adalah formula A (CMC 0, 25\%) dan yang paling kecil adalah formula $\mathrm{B}(\mathrm{CMC} 0,25 \%$; Tween 80 10\%). Hal ini bertolak belakang dengan hasil pengamatan yang dilakukan pada suhu $40-50^{\circ}$ C, dimana persen pemisahan minyak dan air yang terbesar pada formula A (CMC 0,25\%) dan yang terkecil pada formula C (CMC 0,25\% : $\begin{array}{lll}\text { Tween } & 80 & 20 \%) \text {. }\end{array}$

5) Persen pemisahan air pada sentrifugasi $3000 \mathrm{rpm}$

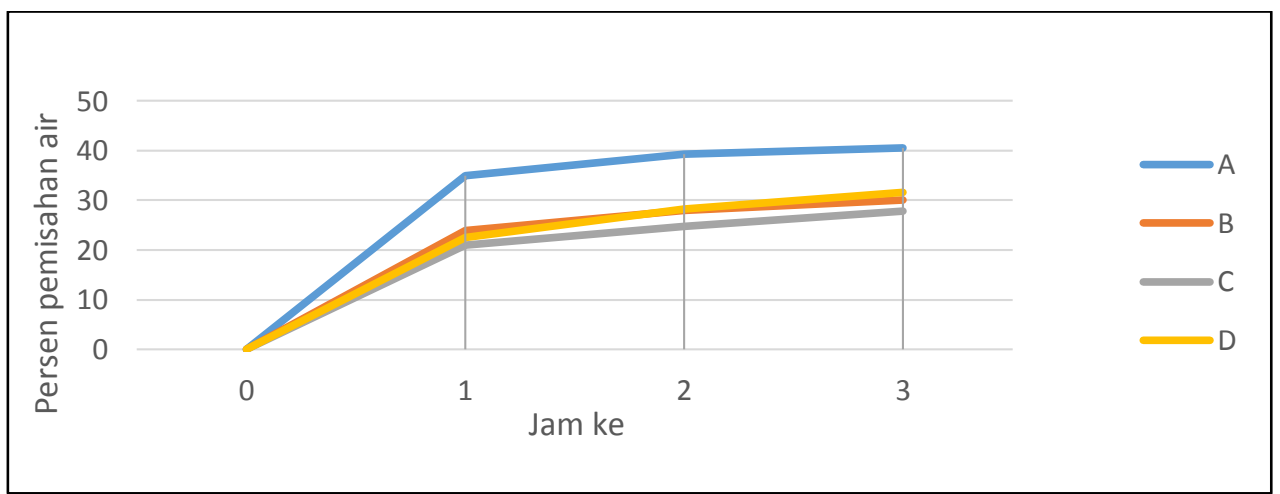

Gambar 5.Grafik hubungan persen pemisahan air dengan lama sentrifugasi.

Hasil pemeriksaan persen pemisahan air pada sentrifugasi $3000 \mathrm{rpm}$ selama 3 jam menunjukkan terjadi pemisahan pada jam ke-1 dengan rata-rata persen pemisahan formula A $35 \%$, formula B 23,85\%, formula C 21,04\%, 
formula D 22,52\% sedangkan pada jam ke-3 rata-rata persen pemisahan formula A 40,50\%, formula B 30,08\%, formula C
$27,76 \%$, formula D 31,62\%.Persen pemisahan air tertinggi pada formula $A$ dan terendah formula C.

6) Persen pemisahan minyak pada sentrifugasi $3000 \mathrm{rpm}$

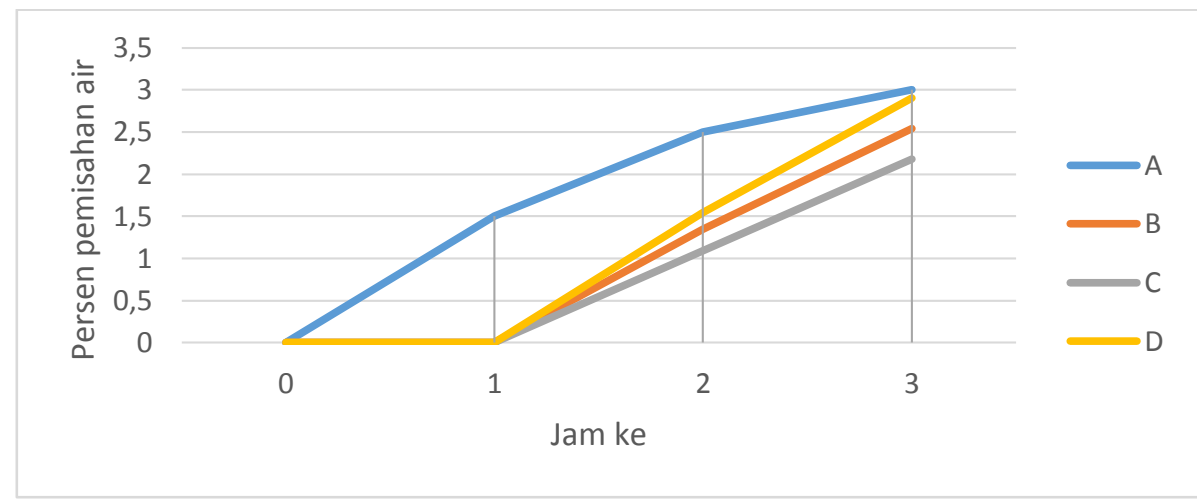

Gambar 6. Grafik hubungan persen pemisahan minyak dengan lama sentrifugasi.

Hasil pemeriksaan persen pemisahan minyak pada sentrifugasi 3000 rpm selama 3 jam menunjukkan formula A terjadi pemisahan pada jam ke-1 dengan rata-rata persen pemisahan $1,5 \%$, sedangkan formula B, C, D mulai terjadi pemisahan pada jam ke-2 sebesar 1,35\%, $1,09 \%, 1,54 \%$ sedangkan pada jam ke-3 rata-rata persen pemisahan formula $\mathrm{A}$ $3,0 \%$, formula B 2,54\%, formula C 2,18\%, formula D 2,90\%.Persen pemisahan minyak tertinggi pada formula A dan terendah formula $C$.

Hasil penelitian persen pemisahan dengan sentrifugasi menunjukkan formula A (CMC 0,25\%) mempunyai persen pemisahan minyak dan air paling besar dan formula C (CMC 0,25\% : Tween 80 $20 \%$ mempunyai persen pemisahan minyak dan air paling kecil.

7) Pemeriksaan viskositas

Tabel III. Hasil pemeriksaan penurunan viskositas emulsi minyak ikan selama 4 minggu

\begin{tabular}{|c|c|c|c|}
\hline \multirow{2}{*}{ Formula } & \multicolumn{2}{|c|}{ Viskositas (cp) } & Penurunan \\
\cline { 2 - 3 } & Minggu ke-0 & Minggu ke-4 & viskositas (cp) \\
\hline A & 131,67 & 40 & 91,67 \\
B & 225 & 140 & 85 \\
C & 338,33 & 260 & 78,33 \\
D & 110 & 110 & 0 \\
\hline
\end{tabular}

Keterangan: Formula dengan emulgator $\mathrm{A}=\mathrm{CMC} 0,25 \%, \mathrm{~B}=\mathrm{CMC} 0,25 \%$ : Tween $8010 \%$, $\mathrm{C}=$ CMC 0,25\% : Tween $8020 \%, \mathrm{D}=$ Tween $8020 \%$ 


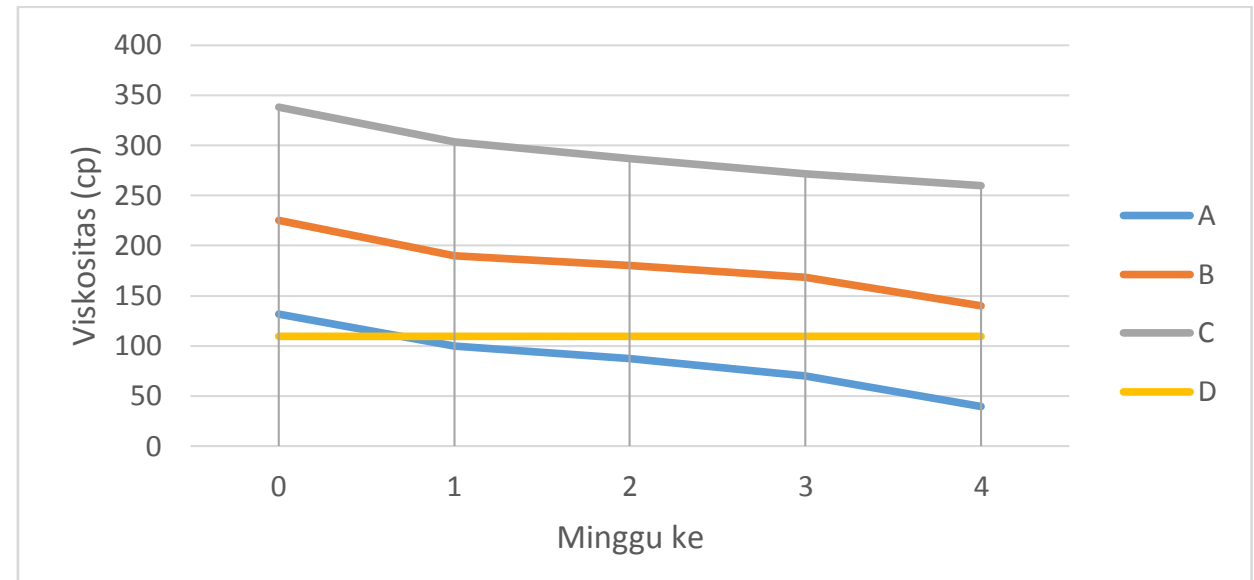

Gambar 7. Grafik viskositas emulsi minyak ikan dari minggu ke-0 sampai minggu ke-4

Pengamatan yang dilakukan dari 4 formula viskositas tertinggi pada minggu ke-0 adalah formula C 338,33 cp dan viskositas terendah formula D $110 \mathrm{cp}$. Pengamatan selama 4 minggu terjadi penurunan viskositas, untuk formula $\mathrm{A}$ 91,67 cp, formula B $85 \mathrm{cp}$, formula C 78,33 cp sedangkan formula D tidak mengalami penurunan viskositas atau stabil.
Hasil penelitian menunjukkan bahwa semakin besar kadar Tween 80, viskositas emulsi minyak ikan semakin kental, penambahan CMC berfungsi sebagai emulgator pembantu yang bekerja dengan cara membentuk lapisan hidrogel sehingga viskositas menjadi lebih kental yang menyebabkan stabilitas emulsi meningkat.

8) Ukuran partikel

\begin{tabular}{|c|c|c|c|}
\multicolumn{4}{c|}{ Tabel IV. Hasil pemeriksaan ukuran partikel } \\
\cline { 2 - 4 } Formula & \multicolumn{3}{|c|}{ Rata-rata ukuran partikel $(\mu \mathrm{m})$} \\
\hline A & 10,24 & 37,38 & 27,14 \\
B & 7,31 & 15,88 & 8,57 \\
C & 6,09 & 14,03 & 7,94 \\
D & 9,30 & 18,13 & 8,83 \\
\hline
\end{tabular}

Keterangan : Formula dengan emulgator A = CMC 0,25\%, B = CMC 0,25\%: Tween 80 10\%, C = CMC $0,25 \%$ : Tween $8020 \%$, D = Tween $8020 \%$

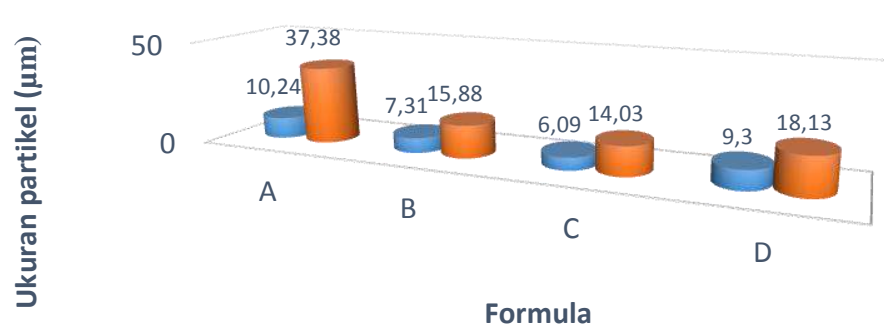

Minggu ke-0 Minggu ke-4

Gambar 8. Grafik ukuran partikel antar formula pada minggu ke-0 dan ke-4 
Pengamatan yang dilakukan dari 4 formula ukuran partikel terbesar pada minggu ke-0 adalah formula A 10,24 $\mu \mathrm{m}$ dan ukuran partikel terkecil formula C 6,09 $\mu \mathrm{m}$. Pengamatan selama 4 minggu terjadi kenaikan ukuran partikel, untuk formula A $27,14 \mu \mathrm{m}$, formula B $8,57 \mu \mathrm{m}$, formula C 7,94 $\mu \mathrm{m}$, formula D $8,83 \mu \mathrm{m}$.

Hukum stokes menyatakan semakin kecil ukuran partikel maka proses terjadinya creaming semakin lama, sehingga diharapkan ukuran partikel sekecil mungkin. Di satu sisi ukuran partikel yang semakin kecil berarti bahwa energi bebas permukaan yang semakin besar sehingga emulsi semakin tidak stabil. Kedua pernyataan tersebut bermakna adanya ukuran partikel yang harus dicapai. Pemeriksaan ukuran partikel menunjukkan bahwa semua formula mengalami pembesaran partikel dengan ukuran partikel paling besar adalah formula A (CMC 0,25\%) dan ukuran partikel paling kecil adalah formula $\mathrm{C}$ (CMC 0,25\% : Tween $80 \quad 20 \%$ ). Pembesaran ukuran partikel dapat terjadi karena adanya koalesen yang menunjukkan shelf life kurang baik dan juga menunjukkan menurunnya viskositas.

\section{B. Pembahasan}

Berdasarkan penelitian yang dilakukan emulsi dengan kombinasi emulgator CMC 0,25\% : Tween $80 \quad 20 \%$ (Formula C) mempunyai stabilitas fisik yang paling baik karena pada sentrifugalsi $3000 \mathrm{rpm}$ selama 3 jam dan pada suhu 40-50 $\mathrm{C}$ persen pemisahannya lebih kecil dibandingkan formula lainnya. $\mathrm{Hal}$ ini diperkuat dengan pemeriksaan ukuran partikel menunjukkan ukuran partikel paling kecil dan pembesaran ukuran partikel selama 4 minggu yang relatif kecil, sedangkan emulsi dengan emulgator CMC 0,25\% (Formula A) mempunyai stabilitas fisik yang buruk karena mempunyai persen pemisahan pada suhu kamar, suhu 40-50 $\mathrm{C}$ dan sentrifugasi paling besar dibandingkan formula lainnya.

Hasil rangkuman dari penelitian terhadap persen pemisahan pada suhu kamar, persen pemisahan pada suhu 40- $50^{\circ}$ C, viskositas dan ukuran partikel menunjukkan ada beda yang berarti antara satu formula dengan formula lainnya sehingga perhitungan dilanjutkan dengan uji Student-Newman-Keuls untuk mengetahui ada atau tidaknya beda yang berarti antar formula.

\section{Kesimpulan dan Saran}

A. Kesimpulan

1. Berdasarkan hasil penelitian pengukuran persen pemisahan pada suhu kamar, suhu $40-50^{\circ} \mathrm{C}$, sentrifugasi $3000 \mathrm{rpm}$ selama 3 jam, viskositas selama 4 minggu dan pemeriksaan ukuran partikel bahwa formula B (CMC 0,25\% ; Tween 80 $10 \%$ ), formula C (CMC 0,25\% ; Tween $8020 \%$ ), formula D (Tween 80 $20 \%$ dapat digunakan sebagai emulgator emulsi minyak ikan karena stabil, sedangkan formula A (CMC $0,25 \%$ ) adalah tidak dapat digunakan sebagai emulgator emulsi minyak ikan karena tidak stabil.

2. Formula emulsi minyak ikan yang paling stabil adalah emulsi dengan kombinasi emulgator CMC 0,25\% ; Tween $80 \quad 20 \%$ karena mempunyai persen pemisahan, ukuran partikel dan penurunan viskositas yang lebih kecil daripada emulsi dengan formula lain.

B. Saran

1. Perlu diteliti lebih lanjut kombinasi emulgator Tween 80 dengan emulgator lain untuk mendapatkan stabilitas emulsi yang lebih baik.

2. Perlu diteliti stabilitas zat aktif minyak ikan dengan penambahan emulgator CMC dan Tween 80.

\section{Daftar Pustaka}

Anief, M. 1993. Farmasetika. Gajah Mada University Press. 175, 176, 180.

Anief, M. 1997. Ilmu Meracik Obat. Gajah Mada University Press. 138-140.

Anief, M. 1991. Apa Yang Perlu Diketahui Tentang Obat. Gajah Mada University Press. 10.

Anief, M. 1999. Sistem Dispersi Formulasi, Suspensi dan Emulsi. Gajah Mada 
University Press. 86-90, 97-99, 103, 132.

Anonim. 1978. Formularium Nasional. Departemen Kesehatan RI. 217.

Anonim. 1979. Farmakope Indonesia. Edisi ke-3. Departemen Kesehatan RI. 455.

Anonim. 1995. Farmakope Indonesia. Edisi ke-4. Departemen Kesehatan RI. 175, 628, 687.

Ansel C, Howard. 1989. Pengantar Bentuk Sediaan Farmasi. Diterjemahkan oleh Farida Ibrahim. UI Press. Jakarta. 357, 378, 379, 387.

Arthur, Alfonso R. G., Harold SM, Ewart A. S, Melvin R. G, Walter K, Liwood F. T, Steward C. H, Alfred N. M, Clarence T. Yin. 1975. Remingions Pharmaceutical Sciences, 15th Ed Mack Publishing Company, Easton Pennysylvania. 1306.

Garret, ER. 1965. Stability of Oil and Water Emulsions. Journal Pharmaceutical Sciences, Vol 54. Number 11, Hal 65.

Lachman, CL. Liberman, H. A, Kanig, J. L, 1986. Theory and Practise of Industrial Pharmacy, Lea and Febiger Philadelphia. Montreal. 502-531.

Lachman, AL. Liberman, H. A, Kanig, J. L. 1994. Teori dan Praktik Industri Farmasi. Diterjemahkan oleh Siti Suyatmi. UI Press. Jakarta. 1029, 1034, 1079, 1082.

Lloyd, K. 1970. Pharmaceutical Suspensions, The Theory and Practise Industrial Pharmacy. Lea and Febriges. Philadelphia. 167.

Martin, A, Swarbick, J., Cammarata, A. 1993. Farmasi Fisik. Diterjemahkan oleh Yoshita, Edisi ke-3. UT Press. 978-1045.

Martin, E. W, Hoover, J. E. 1971. Husas Dispersing of Medication. 1" Ed. Mack Publishing Company. Easton Pennysylvania. 1520.

Martin, E. W, Hoover, YE. 1959. Husas Dispersing of Medication. $5^{\text {th }} \mathrm{Ed}$. Mack Publishing Company. Easton Pennysylvania. 176.
Martono, W. 1998. Informasi Spesialite Obat Indonesia, Vol 31. Ikatan Sarjana Farmasi Indonesia. 139.

Moechtar. 1989. Farmasi Fisika Bagian Larutan dan Sistem Dispersi. Gajah Mada University Press. 129-146.

Moechtar. 1990. Farmasi Fisika Bagian Struktrur Atom dan Molekul Zat Padat dan Mikromiretik. Gajah Mada University Press. 168-198.

Nanizar Zaman, Joenoes. 1998. Resep yang Rasional. Edisi ke-3. Airlangga University Press.

Osol, A. 1975. Remingtons Pharmacentical Sciences, 15th Ed. Mack Publishing Company. Easton, Pennysylvania. 327-339.

Reynolds, J. F. F., eds. 1982. Martindale The Extra Pharmacopeta, $28^{\text {th }}$ Ed. The Pharmaceutical Press. London. 54, 349, 623, 952-960, 1442.

Spowls, B. J. 1963. Prescription Pharmacy, Dosage Formulation and Pharmaceutical Adjuncts. J. B. Lippicant Company. Philadelphia, Montreal. 341.

Voight, R. 1994. Buku Pelajaran Tehnologi Farmasi. Diterjemahkan oleh Soewandi, N. S., Widianto, B. Mathilda. Gajah Mada University Press. 347, 352, 417, 420, 442.

Voight, R. 1995. Buku Pelajaran Tebnologi Farmasi. Diterjemahkan oleh Soewandi, N. S., Widianto, B. Mathilda. Gajah Mada University Press. 398-434. 